\title{
Pengembangan Lembar Kerja Berbasis Pendekatan Terbimbing untuk Memfasilitasi Kemampuan Representasi Matematis Mahasiswa
}

\author{
Erdawati Nurdin \\ Jurusan Pendidikan Matematika, Universitas Islam Negeri Sultan Syarif Kasim Riau \\ e-mail: erdawati.nurdin@uin-suska.ac.id
}

\begin{abstract}
ABSTRAK. Tujuan penelitian ini adalah untuk mengembangkan suatu lembar kerja mahasiswa berbasis penemuan terbimbing yang valid, praktis dan efektif memfasilitasi kemampuan representasi matematis mahasiswa. Penelitian ini merupakan penelitian dan pengembangan (research and development). Penelitian ini mengikuti langkah-langkah model pengembangan ADDIE (Analysis, Design, Developmnet, Implementation dan Evaluation). Teknik pengumpulan data yang digunakan adalah teknik angket dan teknik tes, dengan instrumen berupa angket dan soal tes kemampuan representasi matematis. Data dari angket yang diberikan menunjukkan bahwa LKM yang dikembangkan telah valid dan praktis digunakan. Hasil analisis menggunakan uji U-Mann Withney menunjukkan bahwa LKM efektif memfasilitasi kemampuan representasi matematis mahasiswa. LKM berbasis penemuan terbimbing ini layak digunakan dalam pembelajaran Geometri Analitik, terutama materi Parabola dan Elips.
\end{abstract}

Keywords: ADDIE, geometri analitik, lembar kerja, kemampuan representasi matematis, penemuan terbimbing, penelitian dan pengembangan.

\section{PENDAHULUAN}

Salah satu kemampuan matematis yang harus dimiliki siswa adalah kemampuan representasi matematis (NCTM, 2000). Kemampuan representasi matematis selalu muncul ketika siswa belajar matematika. Siswa akan berusaha memunculkan ide/gagasan dalam berbagai bentuk, baik berupa gambar, grafik, tabel ataupun dalam bentuk verbal demi menemukan solusi bagi permasalahan matematika yang mereka hadapi. Pembelajaran matematika di kelas seyogyanya memberikan kesempatan yang cukup bagi siswa untuk menumbuhkan dan meningkatkan kemampuan representasi matematisnya (Sabirin, 2014). Luitel dan Chandra (Ellianti, Johar dan Husna, 2015) representasi bukan sekedar cara ataupun strategi melainkan bagian dari proses membangun gagasan-gagasan dalam memahami konsep matematis dan sebagai bukti siswa telah memahami konsep.

Memperhatikan pentingnya peranan representasi dalam pembelajaran matematika, maka peserta didik di semua jenjang pendidikan (termasuk perguruan tinggi) haruslah memiliki kemampuan representasi matematis yang baik. Namun, pada kenyataannya kemampuan representasi matematis peserta didik di Indonesia masih rendah. Hal ini dinyatakan oleh Ellianti, Johar dan Husna (2015), bahwa kemampuan representasi matematis siswa SMP masih rendah. Salah satu penyebabnya adalah kesulitan dalam menemukan kata kunci dan memahami informasi yang terdapat di soal dan membuat model matematikanya. Di tingkat perguruan tinggi juga terjadi hal yang sama. Astuti (2017) menyatakan bahwa kemampuan representasi matematis mahasiswa calon guru dalam menyelesaikan permasalahan matematika tergolong masih kurang. Mahasiswa dengan kemampuan akademik tinggi dan sedang (mahasiswa yang memiiki IPK di atas 3) hanya 
memiliki kemampuan representasi matematis pada kategori baik, namun untuk mahasiswa dengan IPK di bawah 3, kemampuan representasinya tergolong rendah.

Materi matematika yang sangat erat kaitannya dengan kemampuan representasi matematis ini adalah geometri. Geometri merupakan materi yang dipelajari dari sekolah dasar hingga perguruan tinggi. Wardhani dan Rumiati (2011) menyatakan bahwa geometri merupakan salah satu konten yang diujikan dalam berbagai survei mengenai prestasi matematika siswa, termasuk survei international yang dilakukan oleh Programme for International Student Assesment (PISA) dan Trends International Mathematics and Science Study (TIMSS). Hal ini menunjukkan pentingnya geometri untuk dipelajari. Salah satu mata kuliah geometri yang dipelajari di tingkat perguruan tinggi adalah mata kuliah Geometri Analitik. Geometri analitik merupakan suatu cabang ilmu matematika yang memadukan aljabar dan geometri. Dengan membuat korespondensi antara persamaan matematika secara aljabar dengan tempat kedudukan secara geometrik diperoleh pemecahan masalah geometri yang lebih sistematik dan lebih tegas. Menggunakan metode geometri analitik untuk membuktikan berarti membuktikan teorema geometri secara analitik (Suarsana, 2014).

Berdasarkan pengalaman peneliti mengajar mata kuliah geometri analitik, mahasiswa calon guru matematika mengalami kesulitan dalam memahami mata kuliah. Mereka masih sulit menemukan teorema geometri dan membuktikan persamaan-persamaan secara aljabar. Selama ini, mahasiswa bersifat pasif dan cenderung hanya menjadi penerima, tidak antusias dalam pembelajaran. Sifat pasif mahasiswa dalam pembelajaran ini berpengaruh pula pada pengetahuan mereka yang rendah. Hal ini dapat dilihat dari rata-rata hasil belajar mata kuliah Geometri Analitik dua tahun terakhir yang hanya berada pada kategori nilai C.

Solusi yang dapat ditawarkan untuk meningkatkan pengetahuan geometri adalah dengan mengubah cara belajar mahasiswa, dari pasif menjadi aktif. Sagala (2003) mengatakan bahwa untuk membantu peserta didik mengatasi kesulitan belajar dibutuhkan suatu prosedur yang sistematis dan terencana. Penemuan terbimbing dapat menjadi pendekatan pembelajaran yang menjadikan mahasiswa aktif menemukan konsep-konsep matematika secara mandiri (Suherman, dkk, 2003). Strategi penemuan terbimbing menekankan kepada pengembangan aspek kognitif, afektif, dan psikomotor secara seimbang, sehingga pembelajaran melalui strategi ini dianggap lebih bermakna (Hamruni, 2012). Ia menambahkan bahwa pembelajaran dengan strategi ini dapat mengembangkan kemampuan berpikir secara sistematis, logis, dan kritis, atau mengembangkan kemampuan intelektual sebagai bagian dari proses mental. Sejalan dengan pendapat tersebut, hasil penelitian Effendi (2012) menunjukkan bahwa kemampuan representasi dan pemecahan masalah matematis siswa dapat ditingkatkan melalui pembelajaran dengan penemuan terbimbing.

Penemuan terbimbing merupakan salah satu pendekatan penemuan dimana guru menyediakan materi atau bahan dan permasalahan untuk penyelidikan siswa. Guru memfasilitasi penyelidikan dan mendorong siswa mengungkapkan atau membuat pertanyaanpertanyaan yang membimbing mereka untuk penyelidikan lebih lanjut (Jauhar, 2011). Pembelajaran penemuan terbimbing merupakan pembelajaran yang berupaya menanamkan dasar berfikir ilmiah pada diri siswa, sehingga dalam proses pembelajaran ini siswa lebih banyak belajar sendiri, mengembangkan kreativitas dalam komunikasi (representasi). Siswa ditempatkan sebagai subyek belajar, sedangkan peran guru dalam pembelajaran penemuan terbimbing adalah sebagai pembimbing dan fasilitator (Jauhar, 2011).

Namun, dalam penerapannya di kelas, pendekatan penemuan terbimbing terkadang memerlukan waktu yang lama (Rohisah, Sunardi dan Sugeng, 2014). Oleh sebab itu perlu digunakan suatu media, alat ataupun bahan ajar yang dapat membantu pembelajaran penemuan terbimbing menjadi lebih efektif dan efesien, salah satunya adalah lembar kerja mahasiswa. Menurut Majid (2012), lembar kerja merupakan alat pendukung perangkat pembelajaran dalam pelaksanaan rencana pembelajaran. Trianto (2011) menyatakan bahwa lembar kerja digunakan sebagai panduan dalam melakukan kegiatan penemuan atau menyelesaikan masalah. Jadi lembar kerja dapat dijadikan sebagai alat dan sumber belajar yang berisikan panduan melakukan kegiatan 
menemukan konsep-konsep matematika. Lembar kerja ini dapat membuat pembelajaran penemuan terbimbing menjadi efektif dan efesien.

Memperhatikan keunggulan penemuan terbimbing yang mampu meningkatkan keaktifan dalam pembelajaran dan meningkatkan kemampuan representasi matematis serta lembar kerja yang menjadikan pembelajaran lebih efektif dan efesien, maka peneliti tertarik untuk melakukan pengembangan lembar kerja matematika berbasis penemuan terbimbing untuk memfasilitasi kemampuan representasi matematis. Penelitian ini bertujuan untuk merancang suatu lembar kerja berbasis penemuan terbimbing yang valid, praktis serta efektif memfasilitasi kemampuan representasi matematis mahasiswa.

\section{METODE}

Penelitian ini merupakan penelitian pengembangan atau research and development $(\mathrm{R} n \mathrm{D})$. Lembar Kerja Mahasiswa (LKM) berbasis penelitian terbimbing ini dikembangkan melalui model pengembangan ADDIE (Analysis, Design, Development, Implementation and Evaluation). Menurut Mulyatiningsih (2013), model pengembangan ADDIE cocok digunakan untuk mengembangkan bahan ajar, seperti modul, lembar kerja dan bahan ajar. Adapun tahapan pengembangan dengan model ADDIE pada penelitian ini dapat dilihat pada diagram berikut :

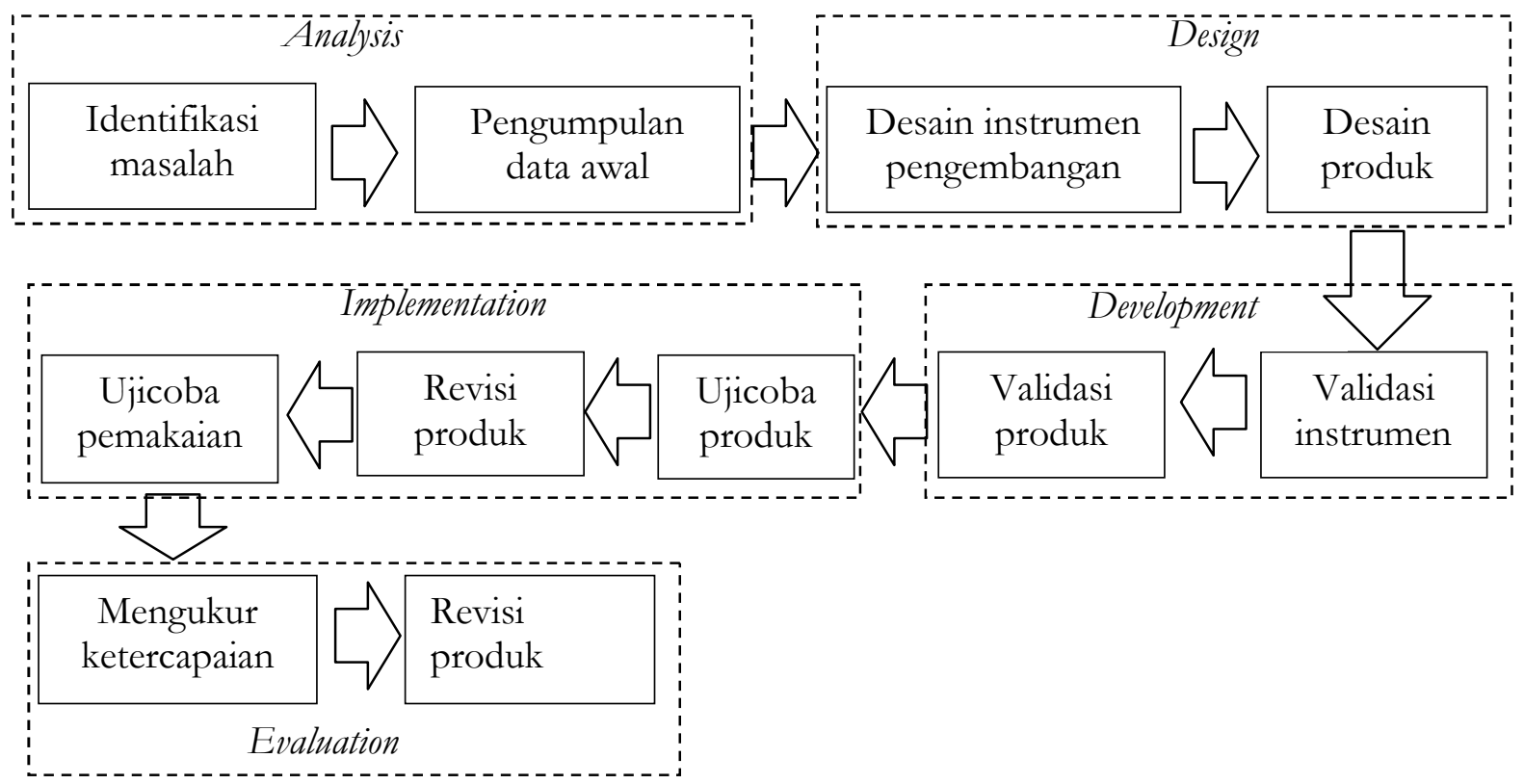

Gambar 1. Diagram Pengembangan LKM dengan Model ADDIE

Untuk memperoleh LKM yang valid, maka LKM divalidasi oleh validator ahli materi dan validator ahli teknologi. Pada penelitian ini, ahli materi memvalidasi LKM berdasarkan aspek konstruk atau konten materi dan validator ahli teknologi memvalidasi berdasarkan aspek tampilan. Kemudian dilakukan uji praktikalitas untuk melihat kepraktisan penggunaan LKM berbasis penemuan terbimbing. Pengujian kepraktisan LKM dilakukan dengan melihat respon siswa. Terakhir, untuk menguji efektifitas LKM dilakukan uji coba (eksperimen) terhadap mahasiswa yang sedang mengambil mata kuliah Geometri Analitik. Eksperimen dilakukan dengan membandingkan rata-rata kemampuan representasi matematis mahasiswa yang diberikan LKM berbasis penemuan terbimbing di kelas eksperimen dengan rata-rata kemampuan representasi matematis mahasiswa yang tidak menggunakan LKM berbasis penemuan terbimbing di kelas kontrol. Adapun desain eksperimen yang akan dilakukan adalah the nonequivalent posttest-only control group design. 
Subjek pada penelitian ini dipilih secara acak, dari empat kelas mahasiswa semester V Jurusan Pendidikan Matematika. Teknik pengumpulan data yang digunakan adalah teknik angket dan teknik tes. Instrumen penelitian yang digunakan adalah angket dan soal tes kemampuan representasi matematis. Angket diberikan untuk memperoleh data validitas dan menjaring respon mahasiswa terhadap penggunaan LKM berbasis penemuan terbimbing. Soal tes diberikan untuk memperoleh data rata-rata kemampuan representasi matematis mahasiswa setelah menggunakan LKM.

Data yang diperoleh dari angket, baik angket validitas maupun angket praktikalitas dianalisis dengan menghitung persentase yang diperoleh. LKM yang dikembangkan dikatakan valid dan praktis apabila masing-masing persentase yang diperoleh lebih dari $80 \%$. Karena data rata-rata kemampuan representasi matematis mahasiswa di kedua kelompok tidak normal, maka analisis dilakukan menggunakan uji non parametrik U-Mann Withney.

\section{HASIL DAN PEMBAHASAN}

Penelitian ini bertujuan untuk mengembangkan LKM berbasis pendekatan penemuan terbimbing yang efektif memfasilitasi kemampuan representasi matematis mahasiswa. Model pengembangan yang digunakan adalah model pengembangan ADDIE, dengan tahapan Analysis, Design, Development, Implementation dan Evaluate.

\section{Hasil}

\section{Tahap Analysis}

Pada tahap ini dilakukan dua analisis, yaitu analisis kinerja dan analisis kebutuhan. Pada tahap analisis kinerja, dirincikan materi yang akan diuraikan pada LKM ini, yaitu materi Parabola dan Elips. Pada bagian parabola, materi yang diuraikan adalah : 1) definisi parabola, 2) persamaan parabola berpuncak di $\mathrm{O}(0,0), 3)$ persamaan parabola berpuncak di $\mathrm{P}(\mathrm{a}, \mathrm{b})$ dan 4) melukis grafik parabola. Pada bagian elips, materi yang diuraikan adalah : 1) definisi elips, 2) persamaan elips berpusat di $\mathrm{O}(0,0), 3)$ persamaan elips berpusat di $\mathrm{M}(\mathrm{h}, \mathrm{k})$ dan 4) melukis grafik elips. Pada tahap analisis kebutuhan, menunjukkan bahwa masih dibutuhkannya bahan ajar untuk menciptakan pembelajaran yang efektif dan efesien. Pada mata kuliah Geometri Analitik ini, bahan ajar yang dibutuhkan berupa Lembar Kerja Mahasiswa (LKM).

\section{Tahap Design}

Terdapat beberapa komponen yang pada LKM berbasis penemuan terbimbing ini, yaitu cover, peta konsep, petunjuk penggunaan LKM, kegiatan pembelajaran yang merujuk pada langkahlangkah penemuan terbimbing, ringkasan, soal latihan, serta daftar pustaka. Adapun tahapan penemuan terbimbing yang dimaksud meliputi: penyampaian tujuan pembelajaran, pemberian petunjuk dan kegiatan penemuan, diskusi hasil penemuan dengan teman, serta presentasi hasil penemuan dan penarikan kesimpulan.

Latihan yang ada pada LKM ini memuat soal-soal yang merujuk pada indikator representasi matematis. Indikator-indikator tersebut yaitu menggunakan representasi berupa gambar, grafik, diagram atau tabel untuk memodelkan dan menginterpretasikan informasi atau data yang diberikan; membuat dan menggunakan representasi matematis untuk mengkomunikasikan ide-ide matematis; serta memilih, menerapkan, dan mengubah antar representasi matematis untuk menyelesaikan masalah. 
Cover

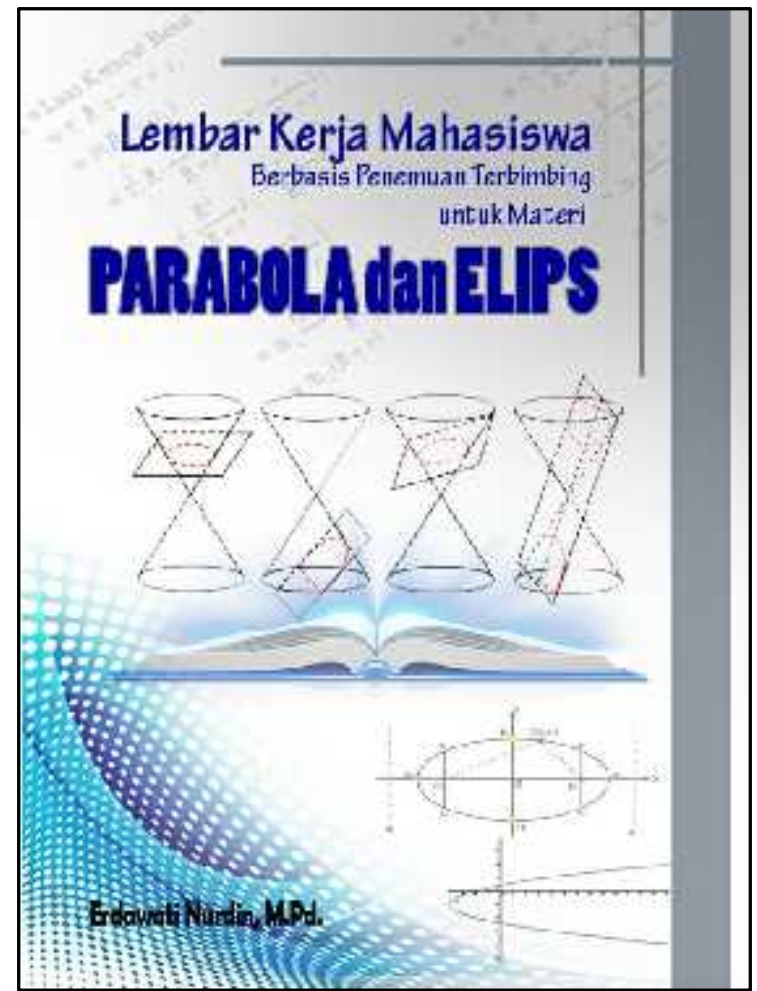

Gambar 2. Desain Cover LKM

Petunjuk Penggunaan LKM

Petunjuk kegiatan ini mengarahkan mahasiswa untuk mengerjakan LKM berdasarkan tahapan pendekatan penemuan terbimbing.

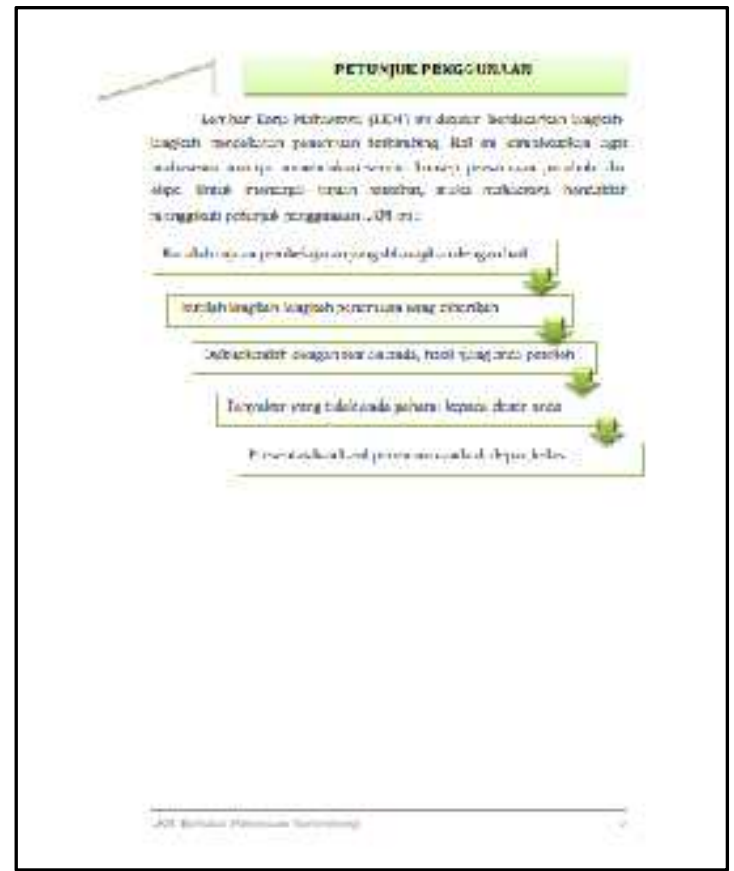

Gambar 3. Desain Petunjuk Penggunaan LKM

\section{Kegiatan Pembelajaran}

Pada kegiatan pembelajran di LKM ini, disusun langkah-langkah kegiatan yang membantu mahasiswa untuk menemukan konsep sesuai tujuan pembelajaran yang diharapkan. 


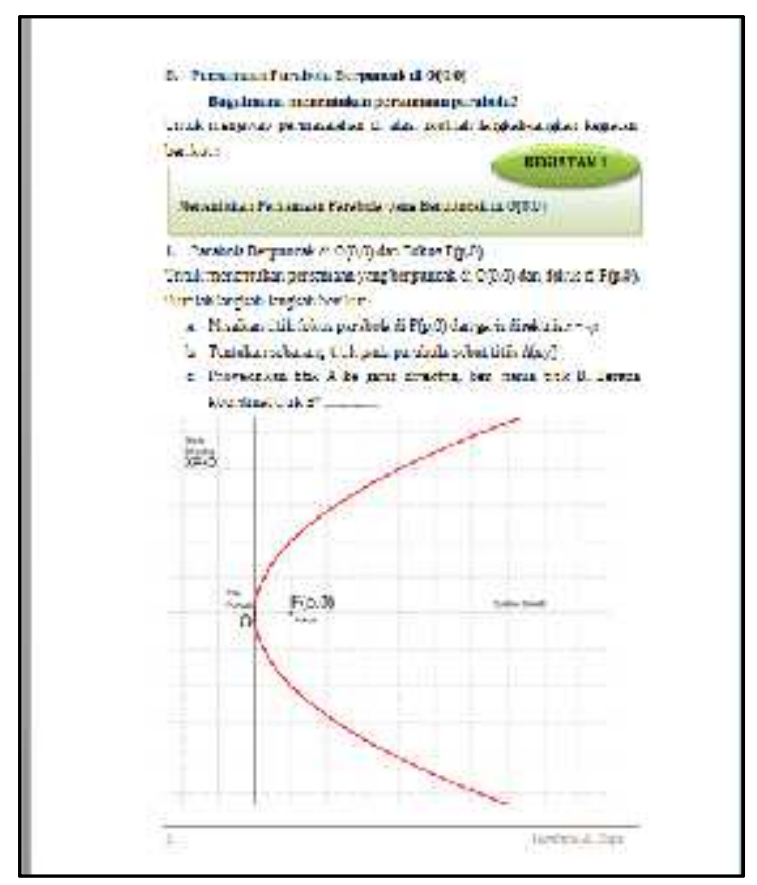

Gambar 4.a. Desain Kegiatan Pembelajaran

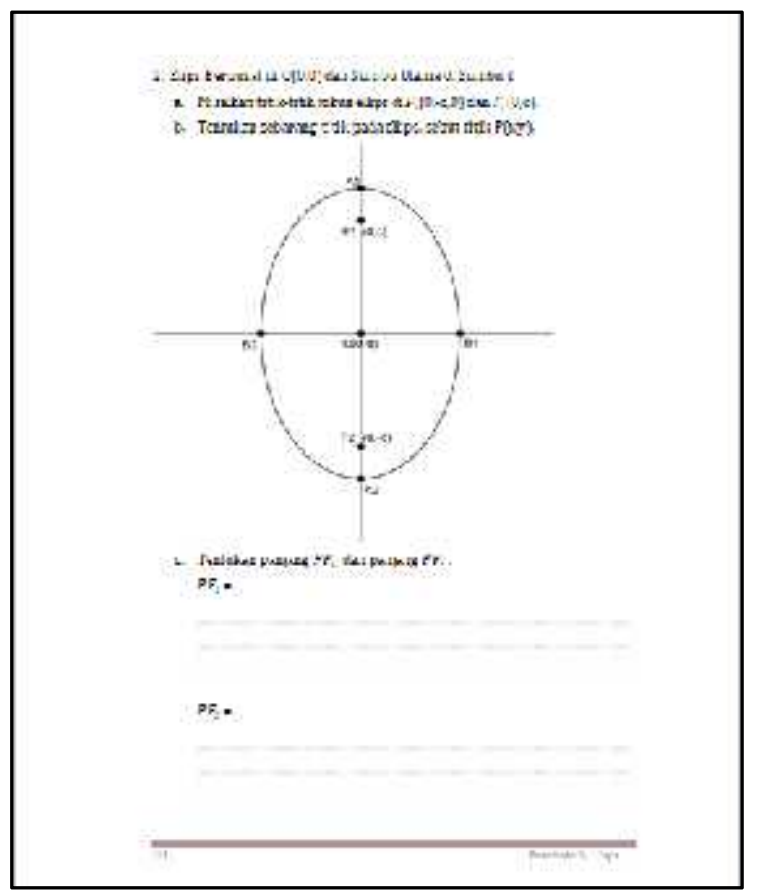

Gambar 4.b. Desain Kegiatan Pembelajaran

\section{Tahap Development}

Selanjutnya, pada tahapan development, LKM yang dikembangkan diuji validitas. Uji validitas dilakukan oleh validator ahli materi dan validator ahli teknologi. Berikut merupakan hasil pengujian validitas LKM berbasis penemuan terbimbing: 
Tabel 1. Hasil Validasi Ahli Teknologi LKM Berbasis Penemuan Terbimbing

\begin{tabular}{clc}
\hline No & \multicolumn{1}{c}{ Aspek } & Nilai Validasi \\
\hline 1 & Penggunaan huruf, nomor dan tulisan & $88,57 \%$ \\
2 & Desain LKM & $80,00 \%$ \\
3 & Penggunaan gambar & $85,00 \%$ \\
4 & LKM secara keseluruhan berpenampilan menarik & $81,11 \%$ \\
\multicolumn{2}{c}{ Rata-rata } & $\mathbf{8 3 , 6 7 \%}$ \\
\hline
\end{tabular}

Selanjutnya, dari segi materi berdasarkan isi atau pembahasan materi baik itu bahasa maupun konsep pembelajaran, hasil Validasi LKM berbasis pendekatan penemuan terbimbing ini dapat dilihat pada berikut :

Tabel 2. Hasil Validasi Ahli Materi LKM Berbasis Pendekatan Penemuan Terbimbing

\begin{tabular}{|c|c|c|}
\hline No & Aspek & Nilai Validasi \\
\hline 1 & Syarat didaktik & $87,27 \%$ \\
\hline 2 & Syarat konstruksi & $86,00 \%$ \\
\hline 3 & $\begin{array}{r}\text { Pendekatan Penemuan Terbimbing } \\
\text { Rata-rata }\end{array}$ & $\begin{array}{l}88,00 \% \\
\mathbf{8 8 , 5 7 \%}\end{array}$ \\
\hline
\end{tabular}

Secara umum, pada pengujian validitas, LKM berbasis penemuan terbimbing ini memperoleh persentase di atas $80 \%$ atau dapat dikatakan sudah valid, namun masih dilakukan beberapa revisi sesuai komentar dan saran dari validator ahli.

\section{Tahap Implementation}

LKM ini selanjutnya diterapkan atau digunakan dalam pembelajaran mata kuliah Geometri Analitik pada materi parabola dan elips. LKM ini diberikan kepada mahasiswa kelas VA Jurusan Pendidikan Matematika, yang berjumlah 25 orang. Setelah memperoleh pembelajaran dengan menggunakan LKM berbasis penemuan terbimbing, mahasiswa diberikan angket untuk menjaring respon mahasiswa terhadap LKM ini. Respon mahasiswa ini digunakan untuk melihat kepraktisan penggunaan LKM berbasis penemuan terbimbing. Adapun hasil uji praktikalitas LKM berbasis penemuan terbimbing sebagai berikut :

Tabel 3. Hasil Uji Praktikalitas LKM Berbasis Penemuan Terbimbing

\begin{tabular}{ccc}
\hline No & Aspek & Nilai Praktikalitas \\
\hline 1. & Pemahaman mahasiswa terhadap materi & $83,92 \%$ \\
2. & Minat siswa terhadap LKM & $81,59 \%$ \\
3. & Penggunaan LKM & $82,77 \%$ \\
& Rata-rata & $\mathbf{8 2 , 7 6 \%}$ \\
\hline
\end{tabular}

Pada pengujian praktikalitas, diperoleh rata-rata persentase respon mahasiswa di atas $80 \%$. Hal ini menunjukkan bahwaLKM berbasis penemuan terbimbing ini dapat dikatakan praktis dalam penggunaanya.

\section{Tahap Evaluation}

Tahapan evaluasi pada penelitian ini dilakukan sejak awal pengembangan. Dimulai dari tahap analisis hingga tahap penerapan. Evaluasi dilakukan dengan melakukan perbaikan-perbaikan sesuai saran validator dan respon mahasiswa. Adapun evaluasi terhadap efektifitas penggunaan LKM berbasis penemuan terbimbing dilakukan dengan melakukan pengujian terhadap rata-rata kemampuan representasi matematis mahasiswa. Pengujian ini dilakukan dengan membandingkan nilai rata-rata yang diperoleh kedua kelompok (kelas kontrol dan kelas eksperimen). 
Sebelum melakukan pengujian terhadap rata-rata kemampuan representasi matematis mahasiswa, berikut diuraikan statistik deskriptif kemampuan representasi matematis mahasiswa :

Tabel 4. Statistik Deskriptif Kemampuan Representasi Matematis Mahasiswa

\begin{tabular}{cccccc}
\hline Kelompok & Rata-rata & Standar deviasi & $\begin{array}{c}\text { Nilai } \\
\text { Maksimum }\end{array}$ & $\begin{array}{c}\text { Nilai } \\
\text { Minimum }\end{array}$ & Skor Ideal \\
\hline Kontrol & 7,31 & 4,98 & 14 & 0 & 16 \\
Eksperimen & 13,80 & 2,10 & 16 & 8 & \\
\hline Pada
\end{tabular}

Pada tabel di atas menunjukkan rata-rata kemampuan representasi kelompok eksperimen lebih baik dibandingkan kelompok kontrol. Namun, untuk memastikan perbedaan ini signifikan maka dilakukan uji statistik inferensial. Pengujian non parametrik U-Mann Withney menunjukkan hasil signifikansi 0,000. Sehingga dapat disimpulkan bahwa terdapat perbedaan di kedua kelompok. Artinya, LKM berbasis penemuan terbimbing ini efektif untuk memfasilitasi kemampuan representasi matematis mahasiswa.

\section{Pembahasan}

Hasil penelitian menunjukkan bahwa nilai rata-rata uji validitas, baik validitas materi maupun validitas teknologi diatas $80 \%$, artinya LKM berbasis penemuan terbimbing yang dikembangkan telah valid. Secara kesuluruhan LKM ini dianggap menarik, dengan kategori baik. Desain LKM tidak ditulis fullcolor dan tidak diberi terlalu banyak gambar karena mempertimbangkan pengguna LKM adalah mahasiswa yang dianggap telah berada pada tingkat berpikir abstrak.

Rata-rata pengujian praktikalitas menunjukkan bahwa mahasiswa memberikan respon positif terhadap penggunaan LKM berbasis penemuan terbimbing ini. Berdasarkan respon yang diberikan mahasiswa, LKM ini mampu menjadikan mereka memahami materi yang disajikan.

Hasil penelitian juga menunjukkan bahwa penggunaan LKM berbasis penemuan terbimbing efektif memfasilitasi kemampuan representasi matematis mahasiswa. Hasil ini sejalan dengan penelitian Purnomo (2011); Arynda, Susanto dan Dafik (2012); Juweni, Sumadji dan Wulandari (2016) menyatakan bahwa pendekatan penemuan terbimbing dapat meningkatkan hasil belajar siswa. Begitu pula, hasil penelitian Effendi (2012) yang menunjukkan peningkatan kemampuan representasi dan pemecahan masalah matematis siswamelalui pembelajaran dengan penemuan terbimbing. Apriyadi (2015) menyatakan bahwa penerapan pembelajaran penemuan terbimbing dapat meningkatkan kemampuan representasi matematis siswa dibandingkan dengan pembelajaran ekspositori. Kegiatan penemuan yang dilakukan berbantuan LKM mengarahkan mahasiswa untuk menemukan konsep sendiri. Penemuan konsep secara mandiri menjadikan pembelajaran lebih bermakna dan memudahkan mahasiswa mengingat konsep yang ditemukan. Setiawan (2017) mengatakan bahwa pembelajaran penemuan terbimbing siswa dituntut untuk aktif dan mandiri dalam memecahkan masalah sehingga siswa memperoleh pemahaman yang benar-benar bermakna.

Setiawan (2017) juga menyatakan bahwa pembelajaran dengan pendekatan terbimbing memerlukan waktu yang cukup lama. Penyajian pembelajaran dengan pendekatan terbimbing dalam bentuk lembar kerja membantu mempersingkat waktu yang diperlukan. Terutama, dalam pembelajaran geometri, dengan menggunakan LKM, mahasiswa tidak perlu waktu lama untuk melukis grafik parabola dan elips. Prastowo (2015) mengungkapkan bahwa lembar kerja dapat dijadikan sebagai bahan ajar yang memudahkan pelaksanaan pembelajaran, mengurangi peranan guru, lebih mengaktifkan siswa untuk belajar mandiri dan membuat materi lebih mudah dipahami oleh siswa. Lebih dalam, Rohisah, Sunardi dan Sugeng (2014); Wijayanti (2016) menyatakan bahwa perangkat pembelajaran berbasis penemuan terbimbing yang dikembangkan efektif meningkatkan hasil belajar siswa. 


\section{KESIMPULAN}

Penelitian ini bertujuan untuk mengembangkan suatu lembar kerja mahasiswa (LKM) berbasis penemuan terbimbing yang valid, praktis dan efektif memfasilitasi kemampuan representasi matematis mahasiswa. LKM dikembangkan mengikuti langkah model pengembangan ADDIE (Analysis, Design, Development, Implementation dan Evaluation). Analisis data yang diperoleh dari angket yang diisi oleh validator ahli materi dan ahli teknologi menunjukkan bahwa LKM berbasis penemuan terbimbing yang dikembangkan telah valid. Analisis data dari respon mahasiswa menunjukkan LKM yang dikembangkan praktis digunakan. Hasil pengujian non parametrik UMann Withney memperlihatkan bahwa LKM berbasis penemuan terbimbing efektif meningkatkan kemampuan representasi matematis mahasiswa. LKM berbasis penemuan terbimbing ini telah layak digunakan dalam pembelajaran Geometri Analitik, materi Parabola dan Elips.

\section{REFERENSI}

Arynda., Susanto., \& Dafik. (2012). Penerapan metode penemuan terbimbing dengan pendekatan kontekstual dalam meningkatkan hasil belajar siswa pada materi aritmatika sosial kelas VIIF semester ganjil SMP Negeri 1 Rambipuji tahun ajaran 2012/2013. Kadikma 3(3),123132.

Astuti, E. P. (2017). Representasi matematis mahasiswa calon guru dalam menyelesaikan masalah matematika. Jurnal Beta, 10(1), 70-82. doi : http://dx.doi.org/10.20414/betajtm.v10i1.100

Apriyadi, S.F. (2015). Pembelajaran matematika dengan metode penemuan terbimbing untuk meningkatkan kemampuan representasi matematis siswa SMA. Prosiding Seminar Nasional Matematika dan Pendidikan Matematika, Universitas Negeri Yogyakarta, 727-732.

Effendi, L.A. (2012). Pembelajaran matematika dengan metode penemuan terbimbing untuk meningkatkan kemampuan representasi dan pemecahan masalah matematis siswa SMP. Jurnal Penelitian Pendidikan, 13(2), 1-10.

Ellianti., Johar, R., \& Husna, A. (2015). Analisis kemampuan representasi matematis siswa kelas ix smpn 6 banda aceh dalam menyelesaikan soal konteks literasi matematika (KLM). Prosiding Seminar Nasional Pendidikan Matematika, Universitas Syah Kuala, 31-45.

Hamruni. (2012). Strategi pembelajaran. Yogyakarta: Insan Madani.

Jauhar, M. (2011). Implementasi paikem dari behavioristik sampai kontruktivistik: sebuah pengembangan pembelajaran berbasis CTL. Jakarta: Prestasi Pustakarya.

Juweni., Sumadji., \& Wulandari. (2016). Penerapan metode penemuan terbimbing untuk meningkatkan hasil belajar siswa. Prosidimg Seminar Nasional Pendidikan Matematika 2016, Universitas Kanjuruban Malang, 177-181.

Majid, A. (2012). Perencanaan pembelajaran. Bandung: PT Remaja Rosdakarya.

Mulyatiningsih, E. (2013). Metode penelitian terapan bidang pendidikan. Bandung: Alfabeta.

National Council of Teachers of Mathematics (NCTM). (2000). Principles and standard forschool mathematics. Reston : NCTM.

Prastowo, A. (2015). Panduan kreatif membuat bahan ajar inovatif. Yogyakarta: DIVA Press.

Purnomo, Y.W. (2011). Keefektivan model penemuan terbimbing dan cooperatif learning pada pembelajaran matematika. Jurnal Kependidikan, 41(1), 37-54.

Rohisah R.V., Sunardi., \& Sugeng P.D. 2014. Pengembangan perangkat pembelajaran matematika berbasis karakter pada model pembelajaran penemuan terbimbing (guided discovery) pokok bahasan teorema pythagoras untuk SMP Kelas VIII. Kadikma, 5(2), 101-110.

Sabirin, M. (2014). Representasi dalam pembelajaran matematika. Jurnal Pembelajaran Matematika, $1(2), 33-44$. 
Sagala, S. (2003). Konsep dan makna pembelajaran. Bandung : Alfabeta.

Setiawan, B. (2017). Pengaruh penerapan model penemuan terbimbing berbantuan power point terhadap hasil belajar materi trigonometri kelas X. Briliant: Jurnal Riset dan Konseptual, 2(4), 504-511.

Suarsana, I.M. (2014). Geometri analitik. Yogyakarta: Graha Ilmu.

Suherman, E, dkk. (2003). Strategi pembelajaran matematika kontemporer. JICA: Bandung.

Trianto. (2011). Mendesain model pembelajaran inovatif-progresif. Jakarta: Kencana Prenada Media Group.

Wardhani, S dan Rumiati. (2011). Instrumen Penilaian Hasil Belajar Matematika SMP: Belajar dari PIS A dan TIMSS. Yogyakarta : Pusat Pengembangan dan Pemberdayaan Pendidik dan Tenaga Kependidikan Matematika.

Wijayanti, D. 2016. Pengembangan Perangkat Pembelajaran Statistik dan Peluang dengan Metode Penemuan Terbimbing Berorientasi Kurikulum 2013 untuk Siswa Kelas X. Jurnal Riset Pendidikan Matematika, 3(1), 23-33. 